\title{
Correction to: Retroperitoneal Robot-Assisted Partial Nephrectomy (rRAPN): Surgical Technique and Review
}

\author{
Moises Rodríguez Socarrás ${ }^{1,2}$ (D) Javier Reinoso Elbers ${ }^{1}$ - Juan Gómez Rivas ${ }^{1}$ - Ana Maria Autran ${ }^{3}$. \\ Francesco Esperto $^{4}$ - Leonardo Tortolero ${ }^{5}$ • Diego M. Carrion ${ }^{1}$ • Fernando Gómez Sancha ${ }^{1}$
}

Published online: 26 June 2021

(C) Springer Science+Business Media, LLC, part of Springer Nature 2021

\section{Correction to: Current Urology Reports https://doi.org/10.1007//11934-021-01051-z}

The original version of this article unfortunately contained a mistake. The author name "Diego Carrion" was incorrect. The original article has been corrected.

Publisher's Note Springer Nature remains neutral with regard to jurisdictional claims in published maps and institutional affiliations.

The online version of the original article can be found at https://oi.org/ 10.1007/s11934-021-01051-Z

Moises Rodríguez Socarrás

moisessocarras@hotmail.com

1 Instituto de Cirugía Urológica Avanzada (ICUA) - Clínica

CEMTRO, Madrid, Spain

2 ICUA, Clínica CEMTROII, Ventisquero de la Condesa 48, $3^{\text {a }}$ planta, 28034 Madrid, Spain

3 Oficina de Investigacion CAU (Confederacion Americana de Urologia), Madrid, Spain

4 Deparment of Urology, Campus-Biomédico University, Rome, Italy

5 Deparment of Urology, IMED Hospitales, Benidorm, Spain 